\title{
Demineralization of Food Waste Biochar for Effective Alleviation of Alkali and Alkali Earth Metal Species
}

\author{
Yoonah Jeong, Ye-Eun Lee $\mathbb{D}^{D}$, Dong-Chul Shin, Kwang-Ho Ahn, Jinhong Jung and I-Tae Kim *D \\ Environmental Resource Research Center, Department of Land, Water and Environment Research, \\ Korea Institute of Civil Engineering and Building Technology, 283, Goyang-daero, Ilsanseo-gu, Goyang-si, \\ Gyeonggi-do 10223, Korea; yoonahjeong@kict.re.kr (Y.J.); yeeunlee@kict.re.kr (Y.-E.L.); \\ dongchulshin@kict.re.kr (D.-C.S.); khahn@kict.re.kr (K.-H.A.); jinhong98@kict.re.kr (J.J.) \\ * Correspondence: itkim@kict.re.kr; Tel.: +82-31-910-0885
}

Citation: Jeong, Y.; Lee, Y.-E.;

Shin, D.-C.; Ahn, K.-H.; Jung, J.; Kim, I.-T. Demineralization of Food Waste Biochar for Effective

Alleviation of Alkali and Alkali Earth Metal Species. Processes 2021, 9, 47. https://doi.org/10.3390/pr9010047

Received: 30 October 2020

Accepted: 25 December 2020

Published: 28 December 2020

Publisher's Note: MDPI stays neutral with regard to jurisdictional claims in published maps and institutional affiliations.

Copyright: () 2020 by the authors. Licensee MDPI, Basel, Switzerland. This article is an open access article distributed under the terms and conditions of the Creative Commons Attribution (CC BY) license (https: / / creativecommons.org / licenses/by/4.0/).

\begin{abstract}
Ash-related issues from a considerable amount of alkali and alkaline earth metal species in biochar are major obstacles to the widespread application of biomass in thermoelectric plants. In this study, food wastes were converted into biochar through pyrolysis at $450{ }^{\circ} \mathrm{C}$ or $500{ }^{\circ} \mathrm{C}$ and four different demineralization approaches, using deionized water, citric acid, nitric acid, and $\mathrm{CO}_{2}$ saturated water. The chemical properties of the resulting biochars were investigated, including proximate analysis, concentrations of inorganic species in biochar and ash, and the crystalline structure. All demineralization treatments produced food waste biochar with sufficient calorific value $(>4000 \mathrm{kcal} / \mathrm{kg}$ ) and a chlorine concentration $<0.5 \%$. Among the inorganic species in biochar, $\mathrm{Na}$ and $\mathrm{K}$ exhibited a significantly higher removal rate through demineralization, which ranged from $54.1 \%-85.6 \%$ and $53.6 \%-89.9 \%$, respectively; the removal rates of $\mathrm{Ca}$ and $\mathrm{Mg}$ were lower than $50.0 \%$. The demineralization method was more critical than the pyrolysis temperature in the removal of alkali and alkaline earth metals. Especially, the lower slagging and fouling tendency was expected for the biochar demineralized with citric acid. Our results suggested that food waste biochar pyrolyzed at $500{ }^{\circ} \mathrm{C}$ and demineralized with citric acid is a promising co-firing material for electric power generation in thermoelectric power plants.
\end{abstract}

Keywords: food waste; biochar; demineralization; ash; AAEM; pyrolysis

\section{Introduction}

With mounting concern over the environmental burden of conventional energy resources, biomass is the focus of alternative fossil fuels. Biomass, with advantages of high energy potential and net neutral carbon emission, was co-fired with coal in thermoelectric power plants [1-5]. Among various sources of biomass, food waste is regarded as an untapped energy resource with a large currently generating and potential future volume and high carbon content [6]. In addition, food waste does not compete with food crops nor does it cause land clearing issues. These characteristics of food waste qualify for sustainable biomass [7].

In the Republic of Korea, approximately $97 \%$ of food waste is recycled, most of which is processed into composting and animal feed. However, the current recycling approaches face practical limitations. Composting and animal feed using food waste are not favored due to the high chlorine content in food waste and the low quality of the final product. As an alternative to conventional treatment methods of food waste in Korea, co-firing of food waste biochar in the thermoelectric power plant was suggested by our research group [8,9]. Co-firing biomass with coal was demonstrated to be the most environmentally favorable method as compared to composting, direct combustion of biomass, and natural gas substitution [10].

However, the combustion of biomass with coal leads to potential corrosion, agglomeration, slagging and fouling, and the generation of fine particulate matter (PM), due to 
a considerable amount of alkali and earth metal (AAEM) species [11,12]. When a large volume of AAEM species in biomass is vaporized, ash-related issues occur. Slagging and fouling reduce the efficiency of energy and heat transfer and hamper the safe operation and maintenance of facilities. The presence of significant amounts of alkali and alkali metal species (AAEMs) is a distinctive characteristic of biomass [13]. Accordingly, several approaches were attempted to reduce the AAEM content in biomass.

Washing biomass with water or acid solution is the most frequently used method [14-17]. As AAEMs in biochar can be divided into water-soluble and water-insoluble, demineralization with acids such as hydrochloric acid, acetic acid, and nitric acid was demonstrated to be the more efficient approach. Other methods include the application of additives and cocombustion $[18,19]$. Although various demineralization techniques were developed, such methods need to be adjusted to target biomass and future applicability.

In this study, we aimed to alleviate the ash content in food waste biochar by applying pyrolysis and subsequent demineralization approaches. Food waste biochar produced in this study satisfied two critical parameters of biomass solid refuse fuel (Bio-SRF), calorific value, and chlorine content, according to international standard BS EN 15359:2011 [20]. The calorific value of food waste biochar was $>5000 \mathrm{kcal} / \mathrm{kg}$ and that of chlorine concentration was $<0.5 \mathrm{wt} . \%$. Specifically, food waste thermally decomposed at either $450{ }^{\circ} \mathrm{C}$ or $500{ }^{\circ} \mathrm{C}$ for $20 \mathrm{~min}$, was prepared and four types of demineralization procedures were tested-(1) washing with deionized water, which is generally known to have a low impact on the structure of biochar [21]; (2) washing with $\mathrm{CO}_{2}$ saturated water, which is shown to enhance the removal of AAEMs by the formation of radical hydrogen and ion exchange between radical hydrogen and the AAEM species [22]; (3) washing with citric acid (CA), a weak acid; and (4) washing with nitric acid (NA), a strong acid. Leaching with strong acid is considered to be a more effective method in the removal of AAEMs; however, unintentional changes in the physicochemical properties of the biochar can occur [15]. Therefore, demineralization procedures with both weak and strong acid were tested. The chemical properties of the biochars were investigated regarding the elemental composition, calorific value, concentration of AAEMs, crystalline structure, and ash composition. The obtained results would provide an optimized preparation method for food waste biochar, and a sustainable solution for the management of food waste, as well as the performance of food waste biochar in a thermoelectric power plant.

\section{Materials and Methods}

\subsection{Biochar Preparation}

Dried food waste was collected from a food waste recovery facility managed by the Gimpo Urban Management Corporation, Korea. Herein, food waste was treated by grinding and dehydration, to produce homogeneous animal feedstuff in powder form. Food waste was collected from a continuous pyrolysis reactor (HM Corp, Hwasung-si, Korea), operated for $20 \mathrm{~min}$ at $450^{\circ} \mathrm{C}$ or $500{ }^{\circ} \mathrm{C}$ (Figure 1). The retention time of biochar in the reactor was much longer than the heating time, which is considered to be a fast pyrolysis process. The input mass of food waste was $10 \mathrm{~kg}$ per operation. The pyrolyzed food waste was collected in a stainless-steel bucket and cooled down to $15^{\circ} \mathrm{C}$. For further experiments, biochar was sieved through a $2 \mathrm{~mm}$ aperture stainless steel sieve. The general experiment scheme and corresponding photos are presented in Figure 1. 


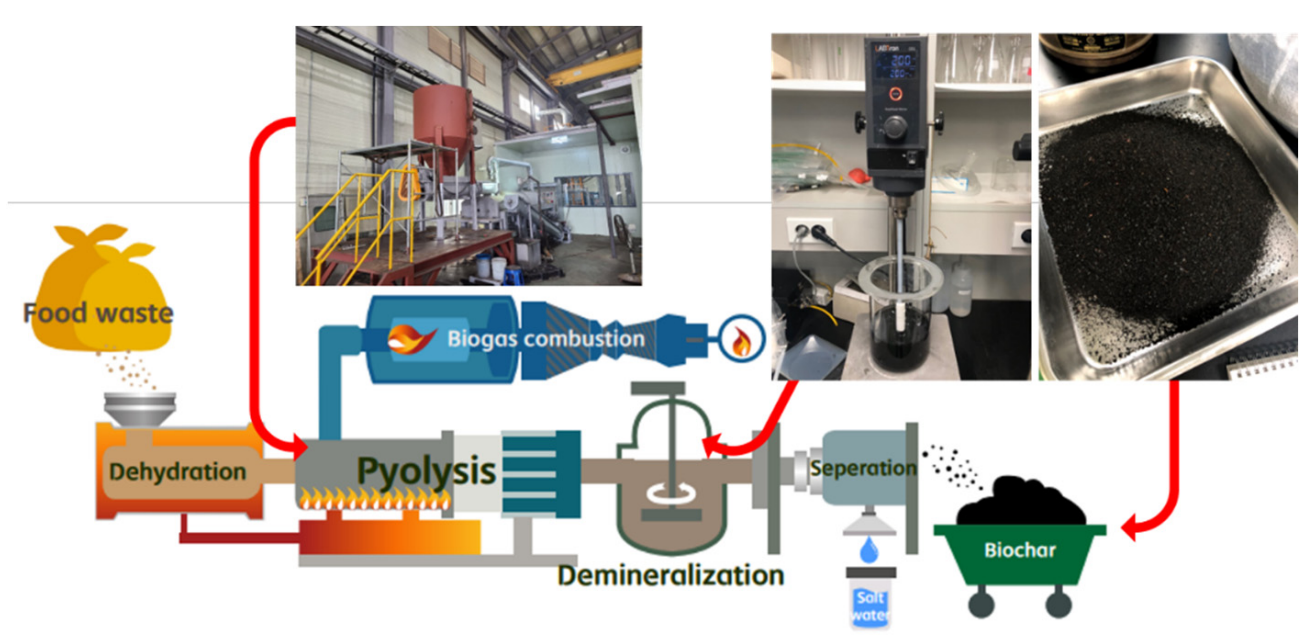

Figure 1. Experiment scheme and photos from food waste to biochar.

\subsection{Biochar Demineralization}

The demineralization experiments were conducted at a 1:10 (m/w) ratio of biochar to solution. Biochar $(50 \mathrm{~g})$ was added to $500 \mathrm{~mL}$ of solution and stirred for $30 \mathrm{~min}$. For water demineralization, deionized water was used; for demineralization using $\mathrm{CO}_{2}$ saturated water, deionized water was purged with $\mathrm{CO}_{2}$ gas $(99.9 \%$, Sodastream, Limburg, Germany), until it reached $\mathrm{pH} 4.5$. Solutions of $3 \%$ citric acid (CA) and $0.1 \%$ nitric acid (NA) were prepared for demineralization using acids. After stirring at each demineralization experimental setup, biochar and the remaining water were separated by a $47 \mathrm{~mm} \mathrm{GF} / \mathrm{C}$ Whatman filter and an electric aspirator (Model A-1000S, EYELA, Tokyo, Japan). In the case of CA treatment, the final $\mathrm{pH}$ was lower than 4, which was too low for the treatment of the washing solution. Accordingly, biochar from the CA treatment went through an additional wash with deionized water to ensure the neutral $\mathrm{pH}$ of the discarded water. Biochar was dried for $24 \mathrm{~h}$ at $70^{\circ} \mathrm{C}$, before further analysis. All experiments were repeated twice independently.

Biochar samples are denoted as $x-y$, where $x$ is the pyrolysis temperature $\left(450{ }^{\circ} \mathrm{C}\right.$ or $500{ }^{\circ} \mathrm{C}$ ) and $\mathrm{y}$ is the demineralization method (B for biochar before demineralization, A for biochar demineralized with deionized water, $\mathrm{CA}$ for biochar demineralized with citric acid, NA for biochar demineralized with nitric acid, and $\mathrm{CO}_{2}$ for biochar demineralized with $\mathrm{CO}_{2}$ saturated water). For example, 500-CA refers to biochar pyrolyzed at $500{ }^{\circ} \mathrm{C}$ and demineralized with citric acid.

\subsection{Characterization of Biochar}

The biochar was characterized to illustrate its performance as a fuel and to compare the efficiencies of the various demineralization techniques. The net calorific value (NCV) was determined using a calorimetric bomb (6400 Automatic Isoperibol Calorimeter, Parr, Moline, IL, USA). Proximate analysis including moisture, ash, volatile matter, and fixed carbon was conducted according to the experimental standard American Society for Testing and Materials (ASTM) D7582. In brief, moisture content (\%) was determined by the difference of initial mass $\left(\mathrm{M}_{\text {initial }}\right)$ and dried mass $\left(\mathrm{M}_{\text {dried }}\right)$, where the temperature was raised from $25{ }^{\circ} \mathrm{C}$ to $105{ }^{\circ} \mathrm{C}$ at a rate of $6{ }^{\circ} \mathrm{C} / \mathrm{min}$ in a nitrogen atmosphere. For the measurement of volatile matter, a weighed sample was heated up to $950{ }^{\circ} \mathrm{C}$ for $7 \mathrm{~min}$ in a nitrogen atmosphere. Then, the sample was heated in an oxygen atmosphere at $800{ }^{\circ} \mathrm{C}$ 
and the residual was determined as the mass of ash $\left(\mathrm{M}_{\mathrm{ash}}\right)$. All parameters were calculated using the following equations:

$$
\begin{gathered}
\text { Moisture }(\%)=\frac{\left(\mathrm{M}_{\text {initial }}-\mathrm{M}_{\text {dried }}\right)}{\mathrm{M}_{\text {initial }}} \times 100 \\
\text { Volatile }(\%)=\left(\frac{\mathrm{M}_{\text {volatile }}}{\mathrm{M}_{\text {initial }}}\right) \times 100-\text { Moisture }(\%) \\
\text { Ash }(\%)=\left(\frac{\mathrm{M}_{\text {ash }}}{\mathrm{M}_{\text {initial }}}\right) \times 100 \\
\text { Fixed carbon }(\%)=100-\text { Volatile }(\%)-\text { Ash }(\%)-\text { Moisture }(\%)
\end{gathered}
$$

Fourier transform infrared (FT-IR) spectrometry (Nicolet 6700, Thermo Scientific, Waltham, MA, USA) was used for qualitative analysis of the biochar structure. Analysis using Inductively Coupled Plasma-Optical Emission Spectrometry (ICP-OES, Agilent 720, Agilent, Santa Clara, CA, USA) was carried out to determine the concentration of AAEM species in biochar in the National Instrumentation Center for Environmental Management in Seoul National University (Seoul, Korea). For sample preparation, microwave digestion was conducted based on the United States Environmental Protection Agency (EPA) method 3051A. The analyzed elements were $\mathrm{Na}, \mathrm{K}, \mathrm{Ca}, \mathrm{Mg}, \mathrm{Fe}, \mathrm{Zn}, \mathrm{Cu}, \mathrm{Ni}, \mathrm{Cd}, \mathrm{Pb}$, and As. Elemental concentrations of the duplicate samples were measured and calculated on a dry matter basis. The crystalline structure of biochar was monitored by X-ray diffraction (XRD) using a DMAX 2500 (Rigaku, Tokyo, Japan; 18 kW, 60 kV/300 mA). Finally, X-ray fluorescence (XRF) analysis (Axios system, Panalytical Co., Ltd., Ea Almelo, The Netherlands) was conducted to investigate the chemical composition of ash after biochar combustion. Except for the raw biochar before demineralization, duplicate samples were analyzed for biochar characterization.

\section{Results and Discussion}

\subsection{Proximate Analysis and Determination of Calorific Value}

The results of proximate analysis and the net calorific value $(\mathrm{NCV}, \mathrm{kcal} / \mathrm{kg})$ are presented in Table 1. As the pyrolysis temperature increased from $450{ }^{\circ} \mathrm{C}$ to $500{ }^{\circ} \mathrm{C}$, the contents of ash and fixed carbon in the biochar before demineralization increased by $2.82 \%$ and $5.59 \%$, respectively. The greater increase in fixed carbon relative to ash was attributed to the conversion of organic volatile matter into fixed carbon, during the pyrolysis process. The higher pyrolysis temperature increased the efficiency of demineralization, resulting in a positive effect on ash reduction.

Table 1. A proximate and calorific value analysis of raw food waste feedstuff and pyrolyzed biochar with different demineralization methods.

\begin{tabular}{cccccc}
\hline & Water (wt. \%) & $\begin{array}{c}\text { Volatile } \\
\text { (wt. } \%)\end{array}$ & Ash (wt. \%) & $\begin{array}{c}\text { Fixed Carbon } \\
\text { (wt. \%) }\end{array}$ & $\begin{array}{c}\text { NCV } \\
\text { (kcal/kg) }\end{array}$ \\
\hline RAW & 8.99 & 72.92 & 8.22 & 9.87 & 4460 \\
\hline \multirow{2}{*}{$450-\mathrm{B}$} & 1.45 & 38.51 & 24.00 & 36.04 & 5160 \\
\hline \multirow{2}{*}{$450-\mathrm{A}$} & 0.94 & 42.35 & 23.39 & 33.31 & 5350 \\
& 1.26 & 42.11 & 22.04 & 34.58 & 5130 \\
\hline \multirow{2}{*}{$450-\mathrm{CA}$} & 1.36 & 42.96 & 18.30 & 37.38 & 5520 \\
& 1.30 & 42.45 & 16.14 & 40.11 & 5340 \\
\hline \multirow{2}{*}{$450-\mathrm{NA}$} & 1.55 & 42.27 & 16.00 & 40.18 & 5630 \\
& 1.18 & 44.77 & 26.37 & 27.68 & 5750 \\
\hline
\end{tabular}


Table 1. Cont.

\begin{tabular}{cccccc}
\hline & Water (wt. \%) & $\begin{array}{c}\text { Volatile } \\
\text { (wt.\%) }\end{array}$ & Ash (wt. \%) & $\begin{array}{c}\text { Fixed Carbon } \\
\text { (wt. } \%)\end{array}$ & $\begin{array}{c}\text { NCV } \\
\text { (kcal/kg) }\end{array}$ \\
\hline \multirow{2}{*}{$450-\mathrm{CO}_{2}$} & 1.41 & 41.51 & 17.70 & 39.38 & 5490 \\
& 1.03 & 43.71 & 24.30 & 30.96 & 5110 \\
\hline $500-\mathrm{B}$ & 1.12 & 30.42 & 26.82 & 41.63 & 5150 \\
\hline \multirow{2}{*}{$500-\mathrm{A}$} & 1.53 & 34.88 & 23.53 & 40.05 & 5020 \\
& 2.63 & 31.70 & 17.77 & 47.90 & 4380 \\
\hline \multirow{2}{*}{$500-\mathrm{CA}$} & 1.75 & 32.67 & 14.15 & 51.43 & 5970 \\
& 1.37 & 32.36 & 12.37 & 53.90 & 6160 \\
\hline \multirow{2}{*}{$500-\mathrm{NA}$} & 1.11 & 34.98 & 23.32 & 40.58 & 5390 \\
& 0.89 & 35.60 & 25.25 & 38.27 & 5290 \\
\hline \multirow{2}{*}{$500-\mathrm{CO}_{2}$} & 1.16 & 33.46 & 17.72 & 47.66 & 5180 \\
\hline
\end{tabular}

A single measurement was carried out for RAW, 450-B, and 500-B. NCV: Net calorific value (kcal/kg); RAW: Raw food waste feedstuff; 450: pyrolysis at $450{ }^{\circ} \mathrm{C}$; 500: pyrolysis at $500{ }^{\circ} \mathrm{C}$; B: biochar before demineralization; A: biochar after demineralization using deionized water; CA: biochar after demineralization using citric acid; NA: biochar after demineralization using nitric acid; and $\mathrm{CO}_{2}$ : biochar after demineralization using $\mathrm{CO}_{2}$ saturated water.

Demineralization had a limited effect on volatiles in biochar but made a noticeable difference to ash and the fixed carbon content. The ash content of raw food waste was $8.22 \mathrm{wt.} \%$ (RAW in Table 1). After pyrolysis, the ash content increased to 13.26-26.82 wt.\%, depending on the pyrolysis temperatures and treatment methods. Although all demineralization methods were effective in reducing the ash content compared to biochar 450-B and 500-B, the most obvious reduction was confirmed as treatment using CA. In case of demineralization using $\mathrm{CA}$, the ash content decreased by $6.78 \%$ and $13.56 \%$ for pyrolysis temperatures of $450{ }^{\circ} \mathrm{C}$ and $500{ }^{\circ} \mathrm{C}$, respectively. Simultaneously, the content of fixed carbon and volatiles showed relative increases.

The net calorific values (NCVs) of all samples were $>4000 \mathrm{kcal} / \mathrm{kg}$, which were acceptable for bio-based solid refuse fuel. Moreover, the calorific values of pyrolyzed and demineralized samples were generally higher than that of the raw material. The calorific value of biochar increased at higher pyrolysis temperatures, despite variations between the demineralization methods. The highest calorific value of biochar was $6065 \mathrm{kcal} / \mathrm{kg}$ (500-CA), $17.77 \%$ increase over 500-B. Overall, pyrolysis and subsequent demineralization contributed to lower the ash content and increase the calorific value.

\subsection{Alkali and Alkaline Earth Metal Contents of Food Waste Biochar}

Among the various elements present in biochar, $\mathrm{Na}, \mathrm{K}, \mathrm{Ca}$, and $\mathrm{Mg}$ (AAEMs) were analyzed by ICP-OES. Other elements $(\mathrm{Fe}, \mathrm{Zn}, \mathrm{Cu}, \mathrm{Ni}, \mathrm{Cd}, \mathrm{Pb}$, and $\mathrm{As}$ ) were also analyzed but the concentrations were less than $2000 \mathrm{mg} / \mathrm{kg}$. These low concentration elements were beyond the scope of this study and were not discussed further. The concentrations of AAEMs with the corresponding removal rates are displayed on a log scale $\left(10^{3}\right.$ to $10^{5} \mathrm{mg} / \mathrm{kg}$ for $\mathrm{Na}, \mathrm{K}$, and $\mathrm{Mg}$; from $10^{3}$ to $10^{6} \mathrm{mg} / \mathrm{kg}$ for Ca; Figure 2). The removal rates of $\mathrm{Mg}$ and $\mathrm{Ca}$ are partly presented because a significant proportion of $\mathrm{Ca}$ and $\mathrm{Mg}$ was retained in biochar after demineralization. Especially, the concentrations of $\mathrm{Mg}$ were consistent for all samples (Figure $2 \mathrm{~b}$ ). However, as the $\mathrm{Mg}$ content was negligible compared to $\mathrm{Na}, \mathrm{K}$, and $\mathrm{Ca}$, this is not discussed further. $\mathrm{Ca}$ is a major element in biochar, and accounted for $>50 \%$ of the total AAEM content; all samples showed high Ca enrichment even after demineralization. 
(a)

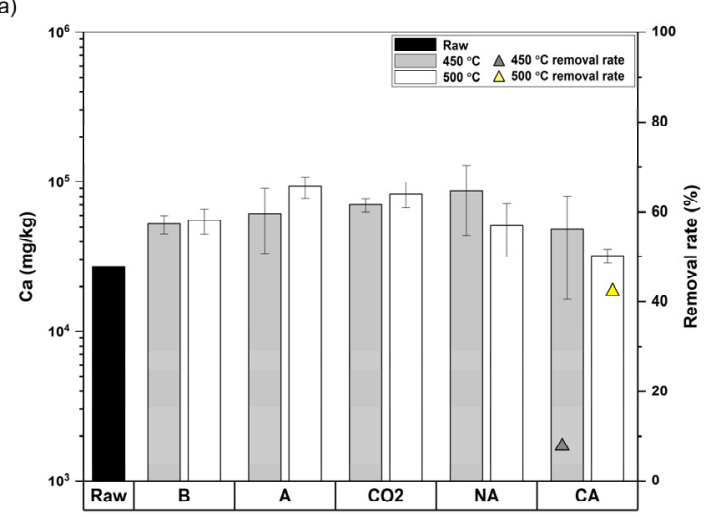

(c)

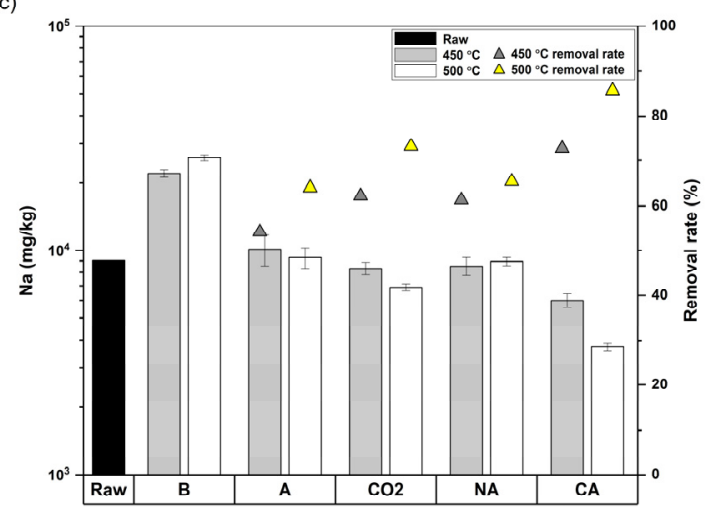

(b)

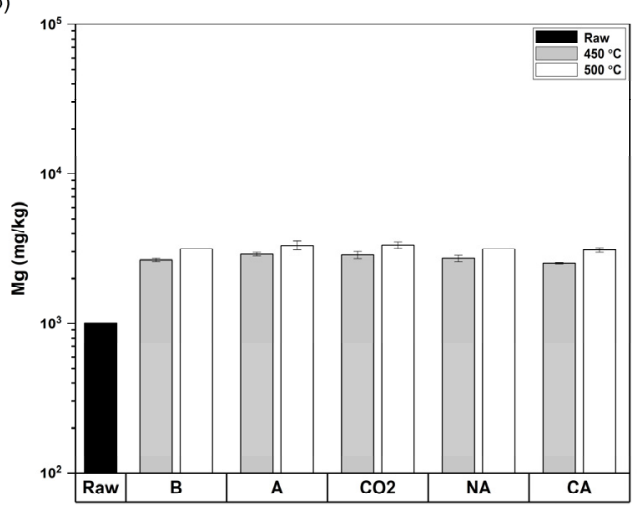

(d)

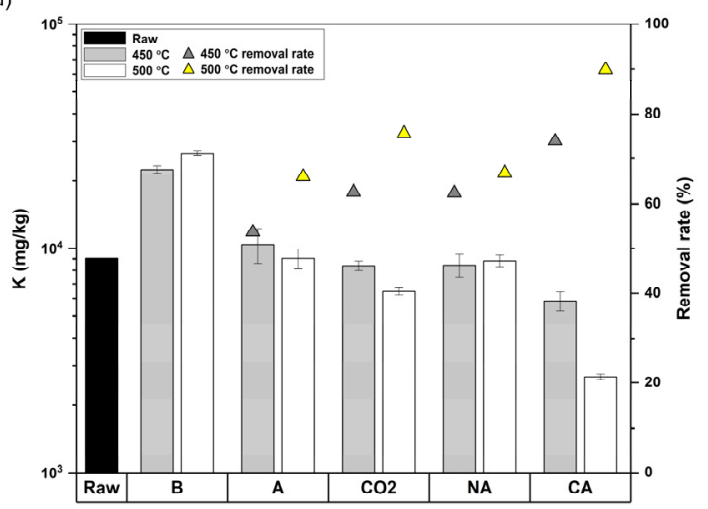

Figure 2. Alkali and alkaline earth metal (AAEM) contents $(\mathrm{mg} / \mathrm{kg})$ and removal rate $(\%)$ of raw biochar samples and those after pyrolysis at $400{ }^{\circ} \mathrm{C}$ and $500{ }^{\circ} \mathrm{C}$; (a) $\mathrm{Ca},(\mathbf{b}) \mathrm{Mg}$, (c) $\mathrm{Na}$, and (d) K. Error bars represent standard deviation $(\mathrm{n}=2)$.

Higher removal rates of the AAEM species $(\mathrm{Na}, \mathrm{K}$, and $\mathrm{Ca}$ ) were found in higher pyrolysis temperatures for all samples. Among them, the influence of pyrolysis temperature was relatively minor for NA, but still noticeable. Based on the comparison of $\mathrm{Na}$ and $\mathrm{K}$ concentration between 450-A and 450-B, and 500-A and 500-B, the proportions of watersoluble $\mathrm{Na}$ and $\mathrm{K}$ in the biochar were approximately $54 \%$ for pyrolysis at $450{ }^{\circ} \mathrm{C}$ and $65 \%$ for pyrolysis at $500{ }^{\circ} \mathrm{C}$ (Figure 2c,d). During the thermal conversion process, chlorine was released in the form of $\mathrm{NaCl}, \mathrm{KCl}$, and $\mathrm{HCl}$ through ion-exchange reactions in the organic matrix of biochar $[23,24]$. After pyrolysis, the chlorine content in biomass increased by $3.37 \%$ (450-B) and $3.39 \%$ (500-B) from $1.16 \%$ (RAW). This concentration change of chlorine was similar to that of $\mathrm{Na}$ and $\mathrm{K}$. Higher pyrolysis temperature increased the relative ratio of water-soluble $\mathrm{Na}$ and $\mathrm{K}$, leading to an efficient reduction of $\mathrm{Na}$ and $\mathrm{K}$ and a lower ash content. Moreover, the lower concentrations of $\mathrm{Na}$ and $\mathrm{K}$ after $\mathrm{CO}_{2}$ saturated water and acid treatment implied that using acid or lowering the $\mathrm{pH}$ of the solution enhanced the removal of $\mathrm{Na}$ and $\mathrm{K} . \mathrm{Na}$ and $\mathrm{K}$ in biochar were relatively easier to remove than $\mathrm{Ca}$ and $\mathrm{Mg}$, most of which were retained even after acid treatment. This was probably because the AAEM species react differently to the pyrolysis temperature. The $\mathrm{Na}$ and $\mathrm{K}$ retained in biochar start to volatilize at $350{ }^{\circ} \mathrm{C}-400{ }^{\circ} \mathrm{C}$, with $\sim 40 \%$ of Na volatilized at approximately $500{ }^{\circ} \mathrm{C}[25,26]$. In contrast, the volatilization of $\mathrm{Ca}$ and $\mathrm{Mg}$ occurs $>600^{\circ} \mathrm{C}$ (i.e., the pyrolysis temperatures in this study are insufficient for $\mathrm{Ca}$ and $\mathrm{Mg}$ volatilization) [27].

Similar removal trends were observed for $\mathrm{CO}_{2}$ and NA treatments, which were also more efficient than deionized water leaching, albeit less so than CA. Interestingly, leaching by the weak acid (CA) showed a better removal than leaching by the strong acid (NA). In the previous study, the application of strong acids was more efficient for the removal of AAEMs [15]. Especially, $\mathrm{Ca}$ and $\mathrm{Mg}$ were almost entirely removed by NA and hydrochloric 
acid (i.e., strong acid). This conflicting result could be attributed to the differences in concentrations between CA and NA. Here, 3\% CA and 0.1\% NA were set to maintain a similar $\mathrm{pH}$ to that of the demineralization solution and to avoid the influence of strong acid on the physicochemical structure of biochar [15]. It is difficult to estimate the removal rate of AAEMs when the same concentrations of CA and NA are applied. Furthermore, demineralization by NA increases the N-bearing compounds in biochar, which could be an additional emission source of NOx during combustion [28].

Changes in the AAEM contents corresponded to the ash content response (Table 1). At a pyrolysis temperature of $450{ }^{\circ} \mathrm{C}$, the reduction in ash ratio with deionized water was $5.33 \%$, increasing to $11.71 \%, 12.50 \%$, and $28.25 \%$ for $\mathrm{NA}, \mathrm{CO}_{2}$, and $\mathrm{CA}$, respectively. In contrast, at a pyrolysis temperature of $500^{\circ} \mathrm{C}$, the ash content decreased by $23.00 \%$ after deionized water leaching, increasing to $28.00 \%$ and $50.55 \%$ for $\mathrm{CO}_{2}$ and $\mathrm{CA}$, respectively. At the same pyrolytic temperature $\left(500^{\circ} \mathrm{C}\right)$, leaching by NA showed the lowest removal of ash content, $9.45 \%$.

\subsection{Structural Characterization of Food Waste Biochar}

Figure 3 presents the FT-IR spectra of biochar samples pyrolyzed at $450{ }^{\circ} \mathrm{C}$ and $500{ }^{\circ} \mathrm{C}$ and treated with the various demineralization methods. Spectra for all biochar samples were similar and there was no obvious generation or extinction of peak. This consistent broad peak between 3300 and $3600 \mathrm{~cm}^{-1}$ in FT-IR spectra indicated -OH stretch of sorbed water and hydrous minerals. The pyrolysis procedure homogenized raw food waste with increased aromatic structures and polymerization, which resulted in a similar band pattern in FT-IR.

The relative intensities of biochar samples varied, as shown in Figure 3. For example, the aliphatic compound C-H stretching peak at 2850 and $2920 \mathrm{~cm}^{-1}$ decreased as the temperature increased to $500{ }^{\circ} \mathrm{C}$ (Figure 3b). This was mainly due to the decreased polar functional groups from the decomposition of organic contaminants. The intensities of the band between 1440 and $1700 \mathrm{~cm}^{-1}$ increased for 450-CA and 500-CA. The peak at $1440 \mathrm{~cm}^{-1}$ represented $\mathrm{C}-\mathrm{O}$ stretching vibration of the carboxyl group, and that at $1700 \mathrm{~cm}^{-1}$ indicated $\mathrm{C}=\mathrm{O}$ stretching of the carbonyl group. These two parameters suggested that an esterification reaction occurred between the hydroxyl groups on the biochar surface and the CA; this elevated the carboxyl and carbonyl peak intensities because the CA was loaded onto the biochar. Consistent results with this study were found in previous studies [29-32].

The application of strong acid on biochar generally leads to changes in morphological and physico-chemical properties [15]. Interestingly, 450-NA and 500-NA did not exhibit a clear difference in FT-IR spectra, compared to the other demineralization methods (Figure 3). This could be attributed to a small NA concentration (0.1\%). A small dose of strong acid was successful in maintaining the consistency in biochar characteristics, but the removal rates of the AAEM species need to be improved. Accordingly, a higher concentration of NA should be tested for efficient demineralization of food waste biochar.

The presence of mineral phases in biochar is shown in the XRD spectra (Figure 4). The XRD pattern for raw food waste (RAW) samples exhibited high noise and background signals, compared to other samples. Overall, calcite $\left(\mathrm{CaCO}_{3}\right)$ was the most noticeable peak for most samples $\left(2 \theta=29.4^{\circ}\right)$, which was consistent with the results of a previous study [26]. With this XRD pattern, it could be assumed that the major proportion of ash content in food waste biochar was $\mathrm{CaCO}_{3}$. The other recognizable peaks were $\mathrm{NaCl}$ and $\mathrm{KCl}$. 
(a)

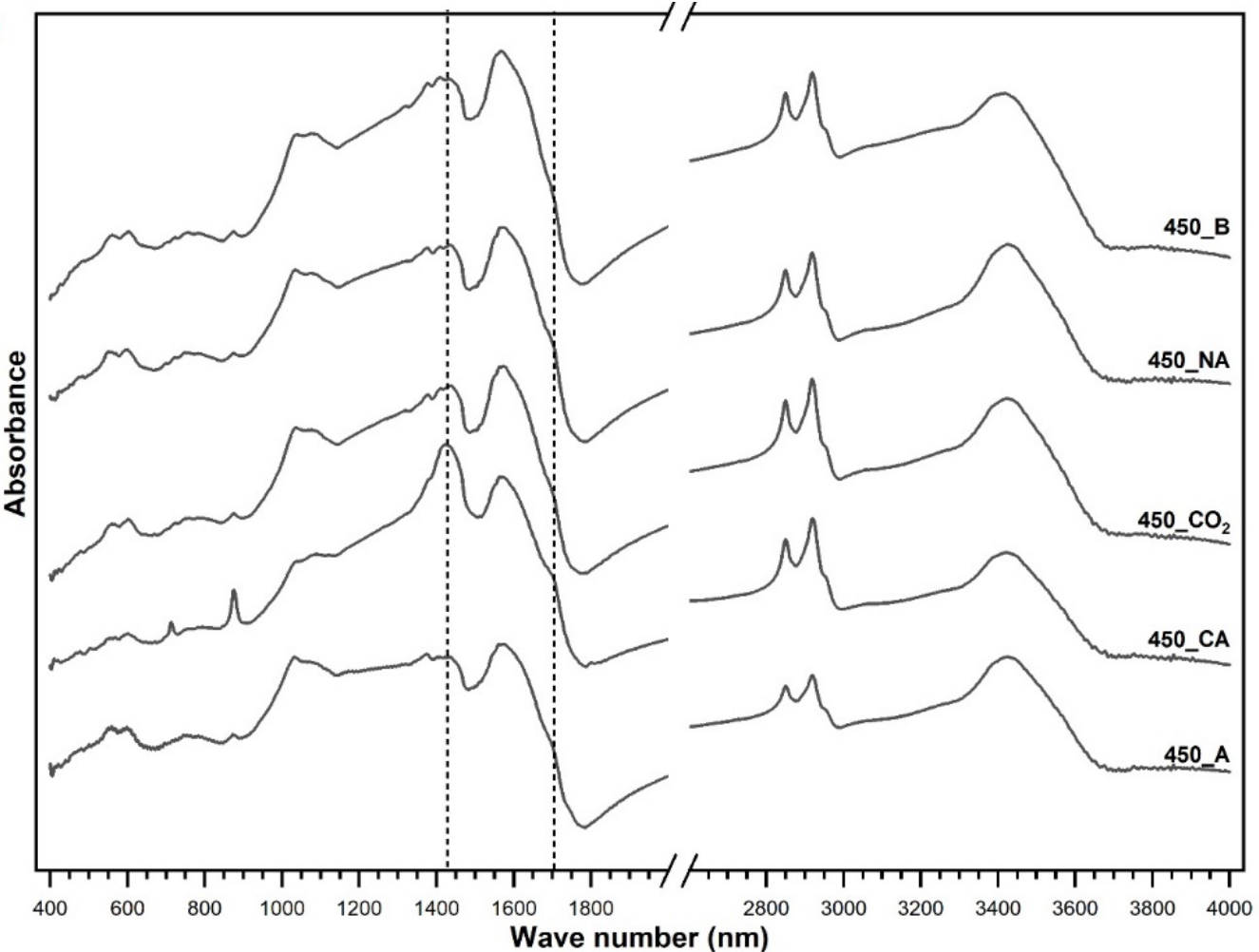

(b)

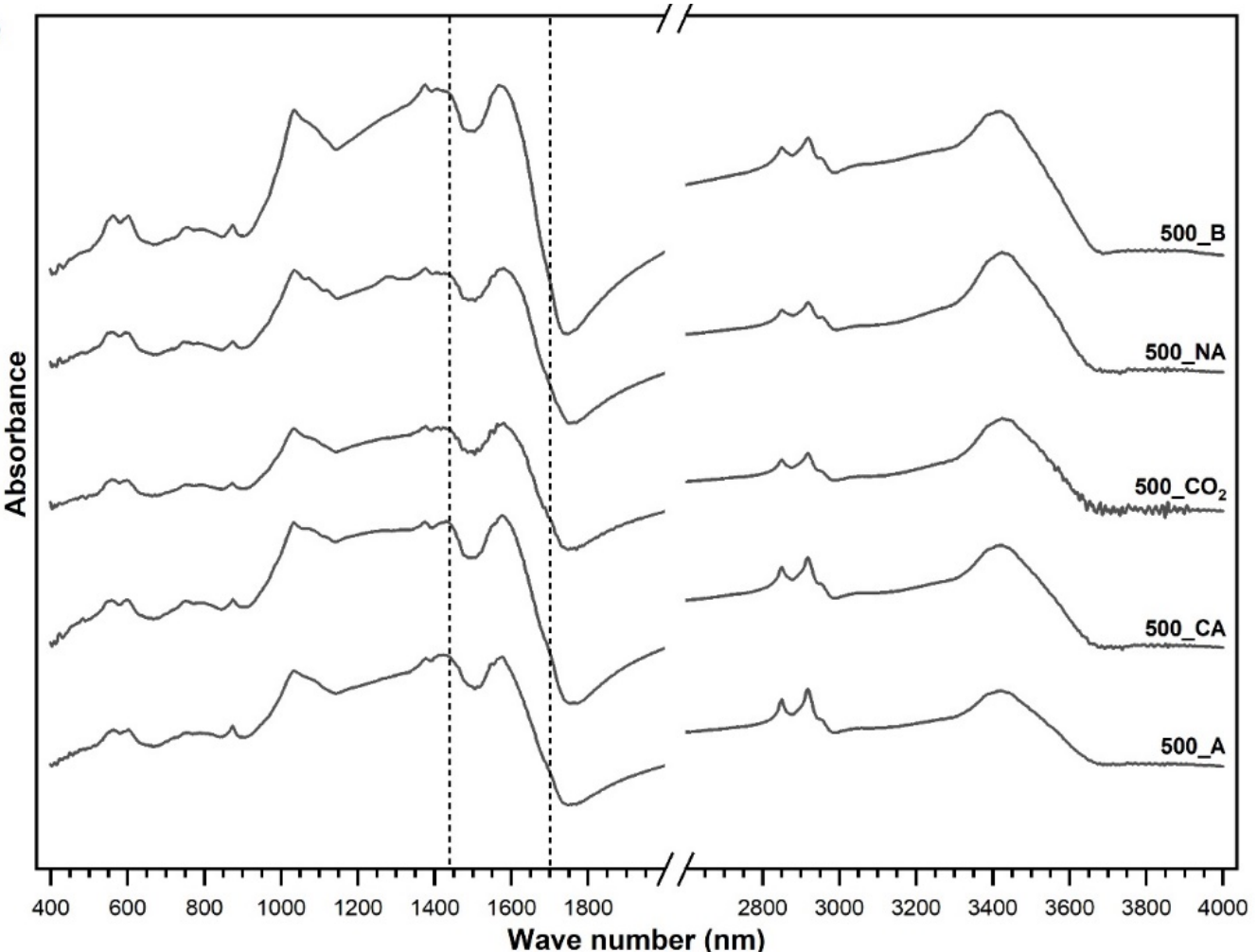

Figure 3. Fourier transform infrared (FT-IR) spectra of biochar pyrolyzed at $450{ }^{\circ} \mathrm{C}\left(\right.$ a) and $500{ }^{\circ} \mathrm{C}(\mathbf{b})$. 

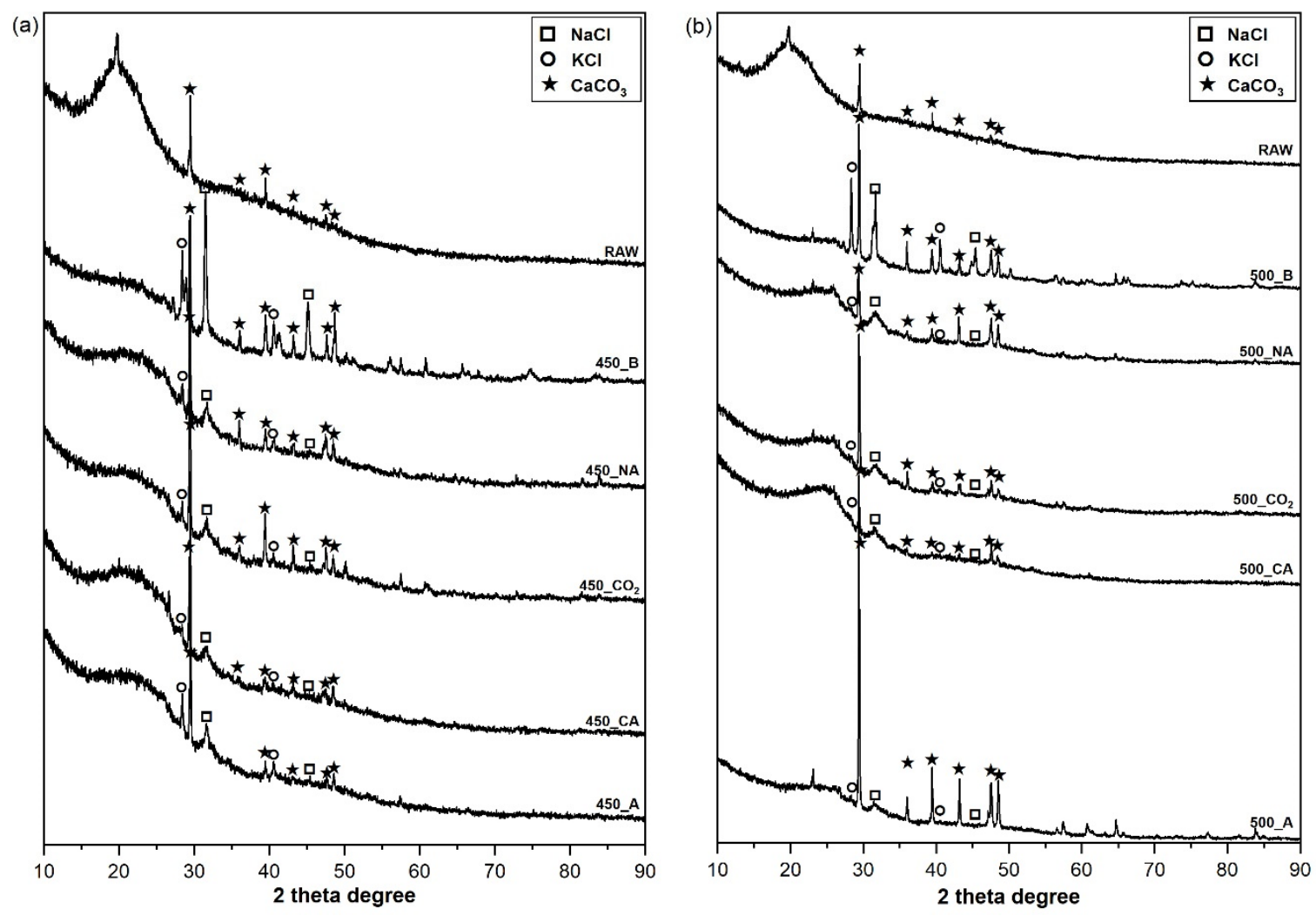

Figure 4. X-ray diffraction (XRD) patterns of biochar pyrolyzed at $450{ }^{\circ} \mathrm{C}(\mathbf{a})$ and $500{ }^{\circ} \mathrm{C}(\mathbf{b})$.

There were apparent increases in peaks between raw food waste biochar (RAW) and biochar after pyrolysis (450-B and 500-B). A possible reason for increments could be that pyrolysis made inorganic species in biochar extractable. Increased crystallization of $\mathrm{KCl}$ was observed at the higher pyrolytic temperature (Figure 4). Increased peak sharpness of chlorine-containing crystals with pyrolytic temperature was also reported in a previous study [27]. The pyrolysis temperature of $500{ }^{\circ} \mathrm{C}$ was not sufficient to decompose $\mathrm{CaCO}_{3}$; however, $\mathrm{CaCO}_{3}$ and $\mathrm{NaCl}$ were more responsive to the demineralization method than to pyrolytic temperature. Distinctive $\mathrm{CaCO}_{3}$ peaks in 500-A and 500- $\mathrm{CO}_{2}$ suggest that the demineralization method affects the crystallinity of biochar (Figure 4b). Peak intensities are not proportional to the concentration because each biochar sample went through various sample preparation procedures. However, the relatively strong intensity of $\mathrm{CaCO}_{3}$ in $500-\mathrm{A}$ and $500-\mathrm{CO}_{2}$ was consistent with the measured concentration of $\mathrm{Ca}$ in biochar (Figure 2). No or low signals were found in samples demineralized by CA (450-CA and 500-CA), which was again in agreement with the ICP-OES results.

\subsection{Ash Composition of Food Waste Biochar}

The chemical composition of the ash was determined by XRF (Figure 5). Raw food waste before pyrolysis (RAW) exhibited a high ratio of Ca content, which was reduced after pyrolysis. With decreasing $\mathrm{Ca}$, the relative concentrations of the other elements including $\mathrm{Cl}$ and $\mathrm{K}$ increased. This indicated that $\mathrm{Ca}$ was partially lost during pyrolysis. According to the XRD results (Figure 4), the dominant form of Ca retained in biochar was $\mathrm{CaCO}_{3}$. In general, $\mathrm{CaCO}_{3}$ starts to decompose at $700{ }^{\circ} \mathrm{C}-800{ }^{\circ} \mathrm{C}$; however, a previous study reported that decomposition can initiate at approximately $400{ }^{\circ} \mathrm{C}-500{ }^{\circ} \mathrm{C}$ if the moisture content is sufficient $[28,29]$. The moisture content of the raw sample (i.e., food waste before pyrolysis) used in this study was $8.99 \%$, which decreased to $1.00 \%-2.08 \%$ after pyrolysis. Therefore, it could be assumed that the partial decomposition of $\mathrm{CaCO}_{3}$ occurred under the influence of moisture during the pyrolysis process. 


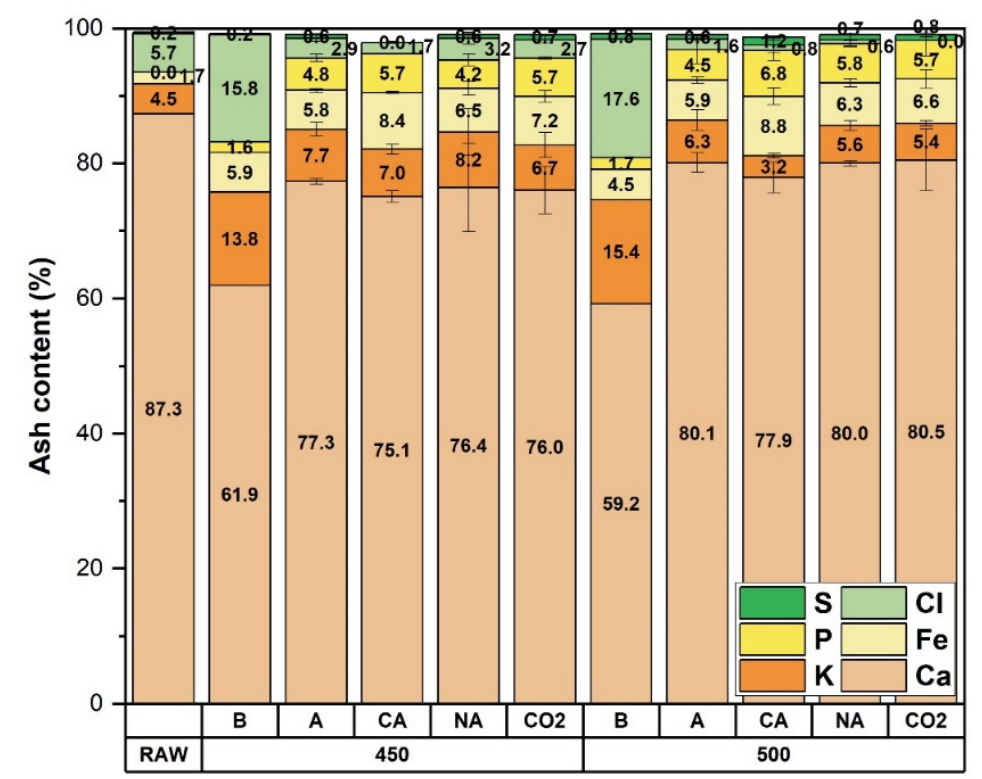

Figure 5. X-ray fluorescence (XRF) results for raw food waste feedstuff and biochar, after different demineralization treatments.

The influence of pyrolysis temperature on chlorine content is clearly shown in Figure 5. After demineralization, the content of $\mathrm{Cl}$ in ash decreased remarkably to less than $3.2 \%$. The amount of residual chlorine in ash was greater at a lower pyrolytic temperature $\left(450^{\circ} \mathrm{C}\right)$ than at a higher pyrolytic temperature $\left(500{ }^{\circ} \mathrm{C}\right)$. As shown in Figure 5, chlorine was not detected in the $500-\mathrm{CO}_{2}$ sample. Considering the chlorine concentration in biochar, it appeared that the amount of volatilized chlorine became more significant at higher pyrolysis temperatures. Note that the chlorine content remained regardless of pyrolysis temperature in raw biochar samples (450-B and 500-B). Taken together, the presence of chlorine in ash depends on the demineralization method rather than on the pyrolysis temperature.

Leaching of inorganic species occurred during the demineralization process, as shown in the ICP-OES results (Figure 2). The removal rates of $\mathrm{K}$ and $\mathrm{Cl}$ in biochar after demineralization were reflected in the concentrations of these elements in ash after combustion. Interestingly, this trend did not apply to the Na content, which was not detected in ash. Considering the content of $\mathrm{Na}$ remaining in biochar (Figure 2), it appeared that residual $\mathrm{Na}$, even after demineralization, was volatilized during combustion. The different volatile behaviors of $\mathrm{NaCl}$ and $\mathrm{KCl}$ during combustion and the influence of demineralization methods require further study.

Demineralization with $\mathrm{CA}$ was the most efficient approach for reducing $\mathrm{Ca}, \mathrm{K}$, and $\mathrm{Cl}$ in ash. This suggests that an esterification reaction between CA and the hydroxyl groups on the biochar surface might hamper the resorption of inorganic species. Both the biochar surface and the carboxyl group of CA act as sorption sites for cations. Furthermore, additional washing with deionized water was conducted in the CA treatment to restore the $\mathrm{pH}$ of the experimental setup. The $\mathrm{H}$ ions in the additional washing water also behave as competitors for AAEM ions. Based on the above observations, the demineralization of biochar using $\mathrm{CA}$ is the most appropriate approach to prevent the slagging and fouling of biochar during combustion.

The ash content represents the non-combustible and non-volatile components of biochar. Since K and Ca were not volatilized during combustion and remained in the ash, the impact of these elements on slagging and fouling should be insignificant. In contrast, $\mathrm{Na}$ and $\mathrm{Cl}$ were found to be volatile, indicating that improved removal of $\mathrm{Na}$ and $\mathrm{Cl}$ during demineralization is a critical factor for the fuelization of biomass. 


\subsection{Practical Implication of Demineralization Approaches on Food Waste Biochar}

The results discussed in Sections 3.1-3.4 showed that biochar pyrolyzed at a higher temperature (i.e., $500{ }^{\circ} \mathrm{C}$ ) was prone to be demineralized. At the demineralization procedure, esterification through the addition of citric acid in biochar produced biochar with a distinguished quality in terms of comparable calorific value with coal and low ash content. Thus, a 500-CA biochar sample was the most suitable cofiring material in this study. However, several technical aspects should not be overlooked.

First, CA treatment consumes more water and generates more wastewater during the demineralization process than other methods. Another environmental issue can be brought along with the high treatment cost of wastewater. Second, although citric acid was applied as an acidifying agent in food and pharmaceutical industries due to negligible toxicity, the addition of chemicals in the process increased the treatment cost. Not only citric acid but also other acids and additives could be adopted as chelating agents to produce highquality biochar $[14,33]$. For example, ethylenediaminetetraacetic acid (EDTA) exhibited similar removal rates of the AAEM species with citric acid, while maintaining neutral $\mathrm{pH}$ conditions [34]. In this regard, potential environmental impacts from additives and wastewater should be considered. In addition, the removal rate of Ca was $42.3 \%$ for the 500-CA biochar sample and the other demineralization approaches should be attempted in further study. Third, co-firing biomass with coal requires various aspects including calorific value, particle size, moisture content, and bulk density [2]. It should be noted that the choice of the demineralization method affects such qualities of biochar.

Last, in this study, biochar was produced in a pilot-scale reactor and processed in the laboratory. This experiment needs to go further outside the laboratory to provide realistic insights into the feasibility of cofiring coal with food waste biochar. The employment of biomass requires proper pre-preparation, such as collection, torrefaction, pyrolysis, pelleting, and pulverization. Even though the potential of cofiring coal with food waste biochar was demonstrated in previous studies [35-38], such pre-preparation needs to be tailored to the purpose of applying biomass and the condition of biomass. In case the food waste biochar is supplied in a thermoelectric power plant on a regular basis, continuous deposition of ash could affect the efficiency of energy generation as well as the maintenance issues. Furthermore, the environmental, economic, and social benefits of using food waste biochar should be balanced in the long run [39].

\section{Conclusions}

In this study, biochar based on food waste was produced for co-firing in thermoelectric power plants, to overcome the limitation of conventional management of food waste and provide a renewable energy resource. The combinations of pyrolysis temperatures and demineralization approaches were tested to identify the optimized treatment for the qualified biochar.

Based on the results of this study, the reduction of Ca content is the most critical factor to prevent slagging and fouling caused by the high AAEM contents. This is because calcium is a major component of food waste biochar and the concentrations of $\mathrm{Na}$ and $\mathrm{K}$ are less significant. $\mathrm{Na}, \mathrm{K}$, and $\mathrm{Cl}$ were not difficult to remove from biochar, while $\mathrm{Mg}$ and Ca were rather refractory. All demineralization methods decreased the AAEM contents in food waste biochar, but the demineralization using CA was the most effective method for reducing ash content without loss of calorific value. Biochar demineralized by CA achieved the highest calorific value $(6160 \mathrm{kcal} / \mathrm{kg})$ and the highest removal rate of $\mathrm{Na}(72.8 \%$ and $85.6 \%), \mathrm{K}(74.0 \%$ and $89.9 \%)$, and $\mathrm{Ca}(7.8 \%$ and $42.3 \%)$, at $450{ }^{\circ} \mathrm{C}$ and $500{ }^{\circ} \mathrm{C}$ respectively. The ash of the food waste biochar consisted of $\mathrm{CaCO}_{3}, \mathrm{NaCl}$, and $\mathrm{KCl}$, where $\mathrm{CaCO}_{3}$ was the most abundant component.

The demineralization method was found to be a determining factor in the removal of inorganic species, while pyrolysis temperature was less critical. Although further studies are required to improve the removal rates of AAEMs (especially $\mathrm{Ca}$ ), the food waste biochar processed in this study would be a suitable co-firing material. 


\begin{abstract}
Author Contributions: Conceptualization, methodology, investigation, writing - original draft preparation, visualization, Y.J. and Y.-E.L.; writing—review and editing, Y.J., formal analysis, K.-H.A., J.J.; investigation, D.-C.S.; supervision, project administration, I.-T.K. All authors have read and agreed to the published version of the manuscript.
\end{abstract}

Funding: This research was funded by the Korea Institute of Civil Engineering and Building Technology (KICT), grant number 20200166-001.

Conflicts of Interest: The authors declare no conflict of interest.

\title{
References
}

1. Velis, C.; Wagland, S.; Longhurst, P.; Robson, B.; Sinfield, K.; Wise, S.; Pollard, S. Solid Recovered Fuel: Influence of Waste Stream Composition and Processing on Chlorine Content and Fuel Quality. Environ. Sci. Technol. 2012, 46, 1923-1931. [CrossRef]

2. Iacovidou, E.; Hahladakis, J.; Deans, I.; Velis, C.; Purnell, P. Technical properties of biomass and solid recovered fuel (SRF) co-fired with coal: Impact on multi-dimensional resource recovery value. Waste Manag. 2018, 73, 535-545. [CrossRef] [PubMed]

3. Tillman, D.A. Biomass cofiring: The technology, the experience, the combustion consequences. Biomass Bioenergy 2000, 19, 365-384. [CrossRef]

4. Lehmann, J. A handful of carbon. Nature 2007, 447, 143-144. [CrossRef] [PubMed]

5. Huang, Y.-F.; Syu, F.-S.; Chiueh, P.-T.; Lo, S.-L. Life cycle assessment of biochar cofiring with coal. Bioresour. Technol. 2013, 131, 166-171. [CrossRef]

6. Lin, C.S.K.; Pfaltzgraff, L.A.; Herrero-Davila, L.; Mubofu, E.B.; Abderrahim, S.; Clark, J.H.; Koutinas, A.A.; Kopsahelis, N.; Stamatelatou, K.; Dickson, F.; et al. Food waste as a valuable resource for the production of chemicals, materials and fuels. Current situation and global perspective. Energy Environ. Sci. 2013, 6, 426-464. [CrossRef]

7. Tilman, D.; Socolow, R.; Foley, J.A.; Hill, J.; Larson, E.; Lynd, L.; Pacala, S.; Reilly, J.; Searchinger, T.; Somerville, C. Beneficial biofuels—the food, energy, and environment trilemma. Science 2009, 325, 270-271. [CrossRef]

8. Lee, Y.-E.; Shin, D.-C.; Jeong, Y.; Kim, I.; Yoo, Y.-S. Effects of pyrolysis temperature and retention time on fuel characteristics of food waste feedstuff and compost for co-firing in coal power plants. Energies 2019, 12, 4538. [CrossRef]

9. Lee, Y.-E.; Jo, J.; Kim, I.; Yoo, Y.-S. Value-added performance and thermal decomposition characteristics of dumped food waste compost by pyrolysis. Energies 2018, 11, 1061. [CrossRef]

10. Peters, J.F.; Iribarren, D.; Dufour, J. Biomass pyrolysis for biochar or energy applications? A life cycle assessment. Environ. Sci. Technol. 2015, 49, 5195-5202. [CrossRef]

11. Reichelt, J.; Pfrang-Stotz, G.; Bergfeldt, B.; Seifert, H.; Knapp, P. Formation of deposits on the surfaces of superheaters and economisers of MSW incinerator plants. Waste Manag. 2013, 33, 43-51. [CrossRef] [PubMed]

12. Oh, H.; Annamalai, K.; Sweeten, J.M. Effects of ash fouling on heat transfer during combustion of cattle biomass in a small-scale boiler burner facility under unsteady transition conditions. Int. J. Energy Res. 2011, 35, 1236-1249. [CrossRef]

13. Wang, Y.; Tan, H.; Wang, X.; Du, W.; Mikulčić, H.; Duić, N. Study on extracting available salt from straw/woody biomass ashes and predicting its slagging/fouling tendency. J. Clean. Prod. 2017, 155, 164-171. [CrossRef]

14. Diaz, L.; Rojas-Pérez, A.; Fuentes-Caraballo, M.; Robles, I.; Jena, U.; Das, K.C. Demineralization of Sargassum spp. Macroalgae Biomass: Selective Hydrothermal Liquefaction Process for Bio-Oil Production. Front. Energy Res. 2015, 3, 6.

15. Jiang, L.; Hu, S.; Sun, L.; Su, S.; Xu, K.; He, L.; Xiang, J. Influence of different demineralization treatments on physicochemical structure and thermal degradation of biomass. Bioresour. Technol. 2013, 146, 254-260. [CrossRef]

16. Ly, H.V.; Kim, S.-S.; Kim, J.; Choi, J.H.; Woo, H.C. Effect of acid washing on pyrolysis of Cladophora socialis alga in microtubing reactor. Energy Convers. Manag. 2015, 106, 260-267. [CrossRef]

17. Davidsson, K.; Korsgren, J.G.; Pettersson, J.; Jäglid, U. The Effects of Fuel Washing Techniques on Alkali Release from Biomass. Fuel 2002, 81, 137-142. [CrossRef]

18. Wang, L.; Hustad, J.E.; Skreiberg, Ø.; Skjevrak, G.; Grønli, M. A critical review on additives to reduce ash related operation problems in biomass combustion applications. Energy Procedia 2012, 20, 20-29. [CrossRef]

19. Yang, T.; Kai, X.; Sun, Y.; He, Y.; Li, R. The effect of coal sulfur on the behavior of alkali metals during co-firing biomass and coal. Fuel 2011, 90, 2454-2460. [CrossRef]

20. BSI BS EN 15359:201. Solid Recovered Fuels. In Specifications and Classes; BSI: London, UK, 2011.

21. Mourant, D.; Wang, Z.; He, M.; Wang, X.S.; Garcia-Perez, M.; Ling, K.; Li, C.-Z. Mallee wood fast pyrolysis: Effects of alkali and alkaline earth metallic species on the yield and composition of bio-oil. Fuel 2011, 90, 2915-2922. [CrossRef]

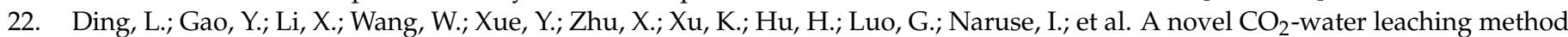
for AAEM removal from Zhundong coal. Fuel 2019, 237, 786-792. [CrossRef]

23. Deng, L.; Ye, J.; Jin, X.; Che, D. Transformation and release of potassium during fixed-bed pyrolysis of biomass. J. Energy Inst. 2018, 91, 630-637. [CrossRef]

24. Wang, S.; Li, Z.; Bai, X.; Yi, W.; Fu, P. Influence of inherent hierarchical porous char with alkali and alkaline earth metallic species on lignin pyrolysis. Bioresour. Technol. 2018, 268, 323-331. [CrossRef] [PubMed]

25. Okuno, T.; Sonoyama, N.; Hayashi, J.; Li, C.-Z.; Sathe, C.; Chiba, T. Primary release of alkali and alkaline earth metallic species during the pyrolysis of pulverized biomass. Energy Fuels 2005, 19, 2164-2171. [CrossRef] 
26. Johansen, J.M.; Jakobsen, J.G.; Frandsen, F.J.; Glarborg, P. Release of K, Cl, and S during Pyrolysis and Combustion of HighChlorine Biomass. Energy Fuels 2011, 25, 4961-4971. [CrossRef]

27. Clemente, J.S.; Beauchemin, S.; Thibault, Y.; MacKinnon, T.; Smith, D. Differentiating inorganics in biochars produced at commercial scale using principal component analysis. ACS Omega 2018, 3, 6931-6944. [CrossRef]

28. Alvarez, R.; Clemente, C.; Gómez-Limón, D. The influence of nitric acid oxidation of low rank coal and its impact on coal 陉. Fuel 2003, 82, 2007-2015. [CrossRef]

29. Wang, H.; Yuan, X.; Zeng, G.; Leng, L.; Peng, X.; Liao, K.; Peng, L.; Xiao, Z. Removal of malachite green dye from wastewater by different organic acid-modified natural adsorbent: Kinetics, equilibriums, mechanisms, practical application, and disposal of dye-loaded adsorbent. Environ. Sci. Pollut. Res. 2014, 21, 11552-11564. [CrossRef]

30. Xu, Y.; Liu, Y.; Liu, S.; Tan, X.; Zeng, G.; Zeng, W.; Ding, Y.; Cao, W.; Zheng, B. Enhanced adsorption of methylene blue by citric acid modification of biochar derived from water hyacinth (Eichornia crassipes). Environ. Sci. Pollut. Res. 2016, 23, 23606-23618. [CrossRef]

31. Lonappan, L.; Liu, Y.; Rouissi, T.; Pourcel, F.; Brar, S.K.; Verma, M.; Surampalli, R.Y. Covalent immobilization of laccase on citric acid functionalized micro-biochars derived from different feedstock and removal of diclofenac. Chem. Eng. J. 2018, 351, 985-994. [CrossRef]

32. Lonappan, L.; Liu, Y.; Rouissi, T.; Brar, S.K.; Surampalli, R.Y. Development of biochar-based green functional materials using organic acids for environmental applications. J. Clean. Prod. 2020, 244, 118841. [CrossRef]

33. Stefanidis, S.D.; Heracleous, E.; Patiaka, D.T.; Kalogiannis, K.G.; Michailof, C.M.; Lappas, A.A. Optimization of bio-oil yields by demineralization of low quality biomass. Biomass Bioenergy 2015, 83, 105-115. [CrossRef]

34. Edmunds, C.W.; Hamilton, C.; Kim, K.; Chmely, S.C.; Labbé, N. Using a chelating agent to generate low ash bioenergy feedstock. Biomass Bioenergy 2017, 96, 12-18. [CrossRef]

35. Lin, Y.-L.; Zheng, N.-Y.; Hsu, C.-H. Torrefaction of fruit peel waste to produce environmentally friendly biofuel. J. Clean. Prod. 2020, 124676. [CrossRef]

36. Pahla, G.; Ntuli, F.; Muzenda, E. Torrefaction of landfill food waste for possible application in biomass co-firing. Waste Manag. 2018, 71, 512-520. [CrossRef] [PubMed]

37. Jeong, Y.; Lee, Y.-E.; Kim, I.-T. Characterization of sewage sludge and food waste-based biochar for co-firing in a coal-fired power plant: A case study in Korea. Sustainability 2020, 12, 9411. [CrossRef]

38. Elkhalifa, S.; Al-Ansari, T.; Mackey, H.; Mckay, G. Food waste to biochars through pyrolysis: A review. Resour. Conserv. Recycl. 2019, 144, 310-320. [CrossRef]

39. Lee, M.; Lin, Y.-L.; Chiueh, P.-T.; Den, W. Environmental and energy assessment of biomass residues to biochar as fuel: A brief review with recommendations for future bioenergy systems. J. Clean. Prod. 2020, 251, 119714. [CrossRef] 